\title{
C-E translation of Red Tourism in Xi'an Based on International Publicity Translation
}

\author{
Chen $\mathrm{Ke}^{1}$ \\ College of Foreign Languages \\ Xi'an Shiyou University \\ Xi'an, China
}

\author{
Yang Fangfang ${ }^{2}$ \\ College of Foreign Languages \\ Xi'an Shiyou University \\ Xi'an, China
}

\begin{abstract}
The mushrooming Red tourist spots in Xi'an are attracting more and more foreigners, while the English propaganda of those attractions is far from standardized. With the practical research to The Eighth Route Army Office Monument in Xi' an and Yang Hucheng Monument etc, the paper analyzes the translation mistakes on syntax, semantic as well as pragmatic level from the perspective of International Publication Translation. By means of cases study of the attractions, we propose transliteration strategies of restructure, conversion, annotation to improve the fidelity and transparency of the English translation both functionally and semantically. The paper is also expected to provide available approaches to promote the acceptability and readability of Red tourism culture, thereby facilitating its dissemination, and shaping a good image for China.
\end{abstract}

Keywords—Red tourism; International Publicity Translation; Conversion; Annotated transliteration

\section{INTRODUCTION}

As the largest developing country in the world, China plays an increasingly important role in the world stage, and it has become the first tourist attraction for a continuously rising number of foreigners influenced by Silk and Road Initiative and other international development strategies. They are keen on Chinese history and culture in which red tourism remains a main stream. Integrating visible revolutionary places, monuments with the invisible spirits they convey, red tourism is a new tendency combining traditional revolutionary elements with tourist industry. With regard to the political sensitivity of Red Culture, the English version is of great significance to disseminate Chinese culture, spread unique revolutionary spirit and shape our country's image. Xi'an is one of the most essential cradles where remarkable red stories, such as Xi'an Accident were taken place. Based on the above information, its English version is rather noticeable to be faithful and expressive [2]. It is widely acknowledged that International Publicity Translation takes Chinese or other languages as source language (SL), English or other ones as target language(SL) to disseminate culture by means of media, magazine etc. Guided by three principles of International Publicity Translation proposed by Huang Youyi, the paper attaches great importance to the acceptability and readability of English version in Xi'an Red Tourism Attractions in order to narrate Chinese stories in an more appropriate way.

\section{The PResent Situation OF C-E TRANSALtion ON Red TOURISM IN XI'AN}

Red tourism in Xi'an is rather typical and popular, yet there are still numerous mistakes in its English version varying from lexical to pragmatic level. The following part will further illustrate and analyze those mistakes from three aspectssyntax, semantic as well as pragmatic level.

\section{A. Mistranslation on syntax level}

Syntax is about principles of forming and understanding English sentences. The form of structure of a sentence is governed by the rules of syntax. These rules specify word order, sentence organization, and the relationship between words, word classes and other sentences elements [5]. In linguistics, syntax is the set of rules, principles, and processes that govern the structure of sentences in a given language, usually including word order [Wikipedia]. On the basis of the above definition as well as explanation, we are aware of that Syntax is a branch of linguistics mainly focused on the lexical aspect, including word meaning, word order etc. By analyzing the research report, we found that mistranslation on syntax level is widely existed. The following examples show the errors in syntax level:

Ex1:

SL: 1937 年 8 月朱德（右）与叶剑英（中)赴南京与国 民政府谈判前与博古（左）在七贤庄的合影。

TL: Zhu De (right), Ye Jianying (middle ) had a photograph taken with BoGu (left) before they went to Nanjing to negotiate with the National Government in August 1937.

The words classes "had a photograph taken with" should be "had taken a photograph with", the latter one is more idiomatic than the previous one.

Ex2:

$\mathrm{SL}$ :在中共中央和中共军委的坚强领导下,西安 “八办” 同志肩负重任,不辱使命完成党中央赋予的 “建立秘密联络 交通,开展隐蔽战线斗争,......坚守红色革命堡垒等” 多项任 务,为中华民族的独立与解放作出了重要贡献。 
TL: Under the leadership of the CPC central committee and the CPC military commission, leaders and staff of the ERAXO made important contribution to the the independence and liberation of the Chinese nation by fulfilling various tasks given by the CPC central committee. Those tasks were to set up to a secret contact point, carry out the underground struggle....and hold firmly this Revolutionary red Stronghold etc.

In the target language, the second sentence is composed by no less than fifteen verbs taking "set up, carry out and hold" as examples, which is peculiar in English, it is not the way to form an English sentence but a Chinese way as verb takes a high proportion in Chinese. The sentence should be translated by diversion or other translation methods based on the comprehension of the sentence meaning. The target language can be: Under the firm leadership of the CPC Central Committee, Central Military Commission, comrades at ERAXO fulfilled various tasks assigned by the CPC Central

Committee. Those tasks were the establishment of Contact Point, the implement of underground struggle, the operation of National Salvation Movement, and the peaceful settlement of Xi'an Accident. They were also dedicated to rescue the scattered, transport the patriotic, protect the military transferring commanders, and to promote the formation of National United Front. Besides, they were committed to purchase and transport goods for the Border Region, rise funds for the Army, expose Anti-Communist conflicts and protect the red revolutionary strongholds etc. All those contributions have exerted great influences on the independence and liberation of the Chinese nation.

Compared the two English versions, it is explicit that the latter one is more accessible to sound natural to native speakers of the English. Syntax is relevant to words and their order. When translating, the translator should get hold of the sentence's meaning first, and then select the most appropriate vocabulary, lexical expressions, and idiomatic expressions which are interculturally equivalent in meaning. Besides, on the premise of comprehending the syntax meaning of source language, the translator can translate freely rather than rigidly adhere to the pattern of source language, but enough attention should be drawn regarding to the idiomaticity in English. Also, vocabulary replacement should be attached great importance owing to the nature of English to avoid monotonousness.

\section{B. Mistranslation on semantic level}

Semantics examines how meaning is encoded in a language [6]. Semantic is not only concerned with meanings of words as lexical items, but also with levels of language below the word and above it[9]. Levels of language below the word and above it is what we are discussing here---the semantic meaning. It is seemingly easy to say that translating in accordance with the context or semantic meaning, yet we can still observe various English translation mistakes in Xi'an Red tourism attractions, the following examples can indicate it vividly:

Ex1:

\section{SL: “剿共” 军事连遭重创.}

TL: "Suppressing the CPC" Military Suffered Repeated Heavy Losses.
"Repeated" means done or happening again and again while "successively" means coming or following one after the other. The target language is expected to express that "heavy loses" happened one after another, therefore, it is "successively" rather than "repeated" should be employed here.

Ex2:

\section{SL: 1962 年,企业用电并入西安电厂, 自建电厂退出历史} 舞台。

TL : After being incorporated in to Xi'an power plant, inhouse power plant ended its existence.

In the above example, “退出历史舞台” is translated into "end its existence", which is not concise here. In the source language context, the author is in expectation to express the meaning that self-built power plant was taken place by industrial power plant, as a result it has to finish its time. However, the phrase "end its existence" is incorrect both grammatically and semantically, if we look up the phrase in dictionary we will find out it is "at the end of one's existence" that is frequently utilized rather than "end one's existence". Hence, we think that " was off its historical stage" is more idiomatic in the above sentence.

Semantic level is related to not only the lexical meaning but also sentence meaning. Both of Chinese and English are polysemantic, which demands the translator must comprehend the specific contextual meaning in essence to make the translation more faithful, informative and readable. Profound professional knowledge as well as cultural background information on the two languages make great contribution to the comprehension of semantic meaning.

\section{Mistranslation on pragmatic Level}

Pragmatics is a subfield of linguistics and semiotics that studies the ways in which context contributes to meaning. Pragmatics encompasses speech act theory, conversational implicature, talk in interaction and other approaches to language behavior in philosophy, sociology, linguistics and anthropology [1]. Pragmatics is the study of meaning in the context [6]. In most cases, we can judge a glossary item and its variants to be chosen by the context in which the item is to be filled in. As we analyzed before, the two languages are distinctly polysemantic, so the glossary of them has their denotative meaning as well as connotative meaning, and we have to get the hold of the meaning in the specific context. For instance, the word "red" has following meanings in English:

\section{1) noun}

(1)any of various colors resembling the color of blood;

(2)the primary color at one extreme end of the visible spectrum, an effect of light with a wavelength between 610 and 780 nanometers.

(3)something red.

(4) (often initial capital letter) Older Slang: Usually a element in politics, especially a Communist.

(5)Informal. red wine. 
(6) Also called red devil, red bird. Slang. a capsule of the drug secobarbital, usually red in color. Etc.

2) Adjective.

(1)of the color red.

(2)having distinctive areas or markings of red:a red robin. of or indicating a state of financial loss or indebtedness:

(3)the red column in the ledger.

(4)Older Slang: Usually Disparaging. Etc.

3) Idioms.

(1)in the red, operating at a loss or being in debt (opposed to in the black):

(2) paint the town red.

(3) see red, Informal. to become very angry; become enraged. Etc.

We can see that the word " red " has various meanings in different sentences or contexts, but here, in this paper, "Red" is the fourth meaning of noun. The contextual meaning is of great significance in intercultural translation, yet the translation in tourism attractions is still inadequate in this part. The following is the analysis of examples in the attractions from pragmatic perspective:

Ex 1:

\section{SL: 坚守西安}

\section{TL:Stick to Xi'an}

The word “坚守” (jianshou) is given several meanings in Chinese. “坚守信念、原则 (jianshou xinnian/yuanze)” means someone sticks to his belief or principle". Here, “ stick to" means someone would not change his mind. “坚持/守梦想” (jianchi/shou mengxiang) is translated into "stick to your dream" . In the above circumstance, “stick to" is in the meaning that someone will continue do the same thing for a rather long time. While in the source language, “坚 守” is expected to express whatever happened, the general will protect $\mathrm{Xi}^{\prime}$ an from the army's attack at that time. In accordance with the context, it is the word " defend" that is more idiomatic.

\section{Ex 2:}

\section{SL: “雄关漫道真如铁,而今迈步从头越”。}

TL: "Tough pass, long trail, like iron. Yet with strong steps We climbed that peak."

The sentence in the source language is excepted from the poem of Mao Zedong( one of Chinese presidents), which is expected to encourage the Red Army to overcome hardships and obstacles with firm beliefs and persistence. The implied meaning is that do not complain the tough pass is hard as the iron, but cross over the peak with strong strides. What we can observe is that in the English version “漫道” is translated into "long trail" , the comprehension to the source language is incorrect, much less the structure and feature of a poem. In respect of the meaning and the rhyme as well as antithesis in the source language, it can be translated into Let alone the harsh strategic pass, Pass over with firm big steps.

The ultimate goal for the English translation is to read by the English-speakers to grasp the corresponding information as well as to communicate. To make the translation more idiomatic, informative and readable, the translator is expected to attach great importance to syntax, semantic aspect, and pragmatic aspect.

\section{TRANSAltion Strategies OF RED TOURISM IN XI'AN}

To improve the fidelity and transparency of English translation version in Xi'an Red tourism attractions, to make the translation more acceptable, the author raises the following three translation strategies based on International Publication Translation perspective.

\section{A. International Publicity Translation}

International Publicity Translation is the translation that takes Chinese as source language, other foreign languages (here particularly mean English) as target language to publicize China with various ways. Three Principles of International Publicity Translation proposed by Huang Youyi, namely close to Chinese reality, the foreigner's requirements towards Chinese information and their way of thinking[3], have great influence on the translation.

\section{B. The Three Translation Strategies}

Guided by the theory and principles, we raise following three translation strategies to promote the English version both functionally and semantically.

\section{1) Restructure}

Restructuring, as one of the translation techniques, means the necessary or inevitable change of the word order in a sentence according to the usage of the target language. It is also called rearrangement or inversion [8]. As we all know that the structure of English differs greatly with that of Chinese as English is accustomed to long sentence while Chinese short ones, the most important information usually is the first part, then the less important part for English but opposite for Chinese. It's necessary to restructure the sentence when we translate to convey sentence meaning faithfully and expressively as we can observe in the following examples:

Ex1:

$\mathrm{SL}$ :今日的西柏坡, 前临碧波荡漾、山水潋洀的西柏坡 湖, 后靠满坡翠柏、松涛阵阵的西柏坡岭, 湖光山色相得益 彰, 形成了独居魅力的秀丽风光。

TL: Now Xibaipo faces the blue ripples of Xibaipo Lake and is nestled against lush green Xibaipo Ridge. The scenery is harmonious, delightful and unique. 
The above translation is obviously restricted by the pattern of the source language yet lack of idiomaticness. With restructuring transaltion skill, the target language can be translated into: Xibaipo is enjoying the unique landscape with the rippling blue lake in the front, the lush pine and cypress on its back. As the integration of the lake and mountains is so gorgeous that the scenery is just like natural craftsmanship.

\section{Ex2:}

\section{SL:海伦.福斯特和埃德加斯诺的第一张合影（1931 年, 杭州)}

TL:First photo taken of Helen Foster and Edgar Snow together in Hangzhou 1931.

In accordance with restructuring translation strategy, the target language is supposed to be The first photo of Helen Foster and Edgar Snow taken in Hangzhou 1931.

\section{2) Conversion}

Conversion, one of the commonly adopted translation techniques, means the change of parts of speech in translation[3]. One of the most obvious differences between Chinese and English is part of speech[6] . Preposition as well as noun take a high proportion in English while verb and adjective in Chinese. What we can acquire from these distinctions is that conversion is indispensable in translating. Here are examples of conversion between the two languages:

\section{Ex1 :}

\section{$\mathrm{SL}$ :八路军驻陕办事处在宣传中国共产党团结抗日的主} 张, 巩固和扩大抗日民族统一战线;领取采购和运输抗战物 资已支援前线;输送爱国人士进步青年和国际友人奔赴延安 和抗日敌后,壮大革命力量等方面做出了突出的贡献。

TL: Shanxi Office has made a great contribution in promoting CPC's unity and resistance; consolidating and expanding the national United Front against Japan; receiving,purchasing and transporting war materiel to support the front transporting Patriots, progressive youth and international friends to Yan'an and strengthening revolutionary forces.

In the target language, there are seven V-ing in the "in" structure, which is Chinglish to a large extent. Guiding by the conversion approach, the target language can be Red Army Office in Xi'an has made great contribution to the publicity of CPC's unity yet anti-Janpanese perspective, the consolidation and expansion of United Front against Japan. It is also dedicated to support war area by purchasing and transporting military material, escort patriotic progressives together with international friends to Yan'an and safe areas, and appeal more and more forces.

\section{Ex2:}

\section{SL:部分爱国军民奋起抵抗,抗日救亡运动风起云涌。}

TL: Some patriotic soldiers and civilians stared the movement.
The above target language doesn't express the source language meaning expressively. With the conversion method, the translation version can be With some patriotic soldiers and civilians stood up to resist the enemy, the tide of anti-Japanese national salvation movement emerged.

\section{3) Adding annotation to transliteration}

Transliteration is the conversion of a text from one script to other[3]. Most system of transliteration map the letters of the source script to letters pronounce similarly in the goal script, for some specific pair of source and goal language. In Chinese, transcription is known as yinyi, it is common to see Chinese noun translated into English using transliteration. For example, 习近平 “Xi Jingping”, 荔枝 “litchi”, 芒果 “mango”, 人参 “ginseng”, 麻将 “mahjong” etc. But, some new Chinese vocabulary are unacquainted if they are translated just by pinyin or other transliteration techniques, especially in Red Tourism Culture. Hence, it is indispensable to add notes to explain, that is what we are illustrating here---Annotated Transliteration. In the following example, it is more proper to translate the source language by annotated transliteration strategy:

\section{SL: 七贤庄是一组占地面积为 13600 平方米的建筑} 群,1934 年冬天由陕西省银行投资修建,1936 年建成并对外 出租。

Tl: QianXianZhuang, covered an area of 13600 square meters, was built by Shaanxi Provincial Bank in winter of 1934

The context of the source language is the introduction of Qi Xianzhuang. Referring to the correlative information, Qi Xianzhuang and The Eighth Army Office Monument in Xi'an is the same place but different names. However, most people are familiar with the later name rather than the first one, so it's necessary to translate the place name by pinyin first, and then take a note. The English version can be: With an area of 1,3600 square meters, in winter of 1934, QianXianZhuang (the location of the Eighth Route Army Office) was under construction invested by Shaanxi Provincial Bank, and in 1936 it started to rent.

The above three translation strategies---restructuring, conversion, and annotated transliteration are aimed at dealing with the syntax, semantic together with pragmatic problems in Red Tourism translation, specifically, the lexical choices, collaboration, replacement, the sentence structure, and the contextual meaning etc. With practical research and analytical report, the approaches we raise are in expectation to make it accessible to read fluently and idiomatically.

\section{ANAlysis BASED ON THE PERSPECTIVE OF \\ INTERNATIONAL PUBLICITY TRANSLATION, CONCLUSION}

Red tourism is a flourishing tourism symbolizing the unique crystallization of Chinese nation [7]. Red culture is not only a formalization to commemorate Chinese history and development, but also an invisible property to advance, to inherit the predecessors' persistent and independent spirit. The translation towards relative materials is of great significance as 
it enriches Chinese culture, meanwhile shapes the image of China in global community.

With the practical research, the paper analyzes the mistranslation of Red tourism attractions in Xi'an from the International Publicity Translation perspective, and raises three translation techniques towards the mistranslation phenomenon, they are restructuring, conversion and annotated transliteration to improve the readability and acceptability of English version. Promoting the fidelity and transparency is also in our expectation. All examples in the paper are extracted from the Red tourism attractions of Xi'an. Apart from the translation errors in those places, other problems like the lack of English version in many Red tourism attractions, such as Xi'an Revolutionary Park etc, and the lack of bilingual interpreters etc will also effect the comprehension and publicity of Red tourism culture. The optimization and supplement in those aspects are in expectation as well.

Red tourism is a booming industry with unique Chinese character as well as profound cultural sentiment, its English translation weights the image of Xi'an, even that of China at a large extent. On the basis of International Publicity Translation, the paper is supposed to strengthen the fidelity and transparency of its English version, to boost the readability and acceptability of that, and to foster its advancement together with dissemination.

\section{ACKNOWLEDGMENT}

The paper is a periodical result of Scientific Research Program Funded by Shaanxi Provincial Education Department The C-E translation of Red Tourism in Shaanxi Province from the Perspective of Eco-translatology (Program No.18JK0595).

\section{REFERENCES}

[1] M, Jacob L. Pragmatics: An Introduction [M]. Oxford: Blackwell , 2nd ed, 2001.

[2] Nida, E.A. Language, Culture and Translating[M]. Shanghai: Shanghai Foreign Language Education Press,2000.

[3] Kharusi, N.S.\&Salman, A. The English Transliteration of Place Names in Oman. Journal of Academic and Applied Studies Vol. 1(3) September 2011, pp. 1-27 Available online at.

[4] Huang YY. Addressing Difficult Issues in International Publication Translation Based on Three Closeness Principles. Chinese Translators Journal,6,pp.26-28,2004. (In Chinese)

[5] Hu. Z.L, Liu.R.Q, Li. Y.F. Workbook for Linguistics: A Course Book, 5th ed. Peking University Education Press,2017, pp14-17.

[6] Chen,S.Y. International Publicity Translation: Wrestling of Ideologies. Journal of Changsha University of Science\&Technology, 3,90-95.

[7] Wang,J.Y. Pragmatic Equivalent Translation in Intercultural Tourism English. Journal of Xianning University, 5,90-91,2009.

[8] Jin,H.K. Intercultural Communication and Translation [M]. Beijing: China Translation Corporation,2003.

[9] He. Z.R. A Study of Pragmatics [M]. Human Education Press, 1987. 